\title{
Typological classification of clayey raw materials for ceramics manufacture, in the Tábua region (central Portugal)
}

\author{
José V. V. Lisboa · Jorge M. F. Carvalho • \\ Pedro P. Cunha · Álvaro Oliveira
}

Received: 9 February 2012/Accepted: 15 January 2013/Published online: 8 March 2013

(c) Springer-Verlag Berlin Heidelberg 2013

\begin{abstract}
Mapping of clay resources in the Cenozoic deposits of the Tábua region (central Portugal) has been carried out, together with the chemical, mineralogical and technological characterization of seventeen clay samples. The study was undertaken to relate the lithostratigraphic units and the typology of raw materials with regard to the manufacture of ceramics. The sedimentary succession comprises two units with different suitability for the manufacture of ceramics: an upper unit, with clays that present technological restrictions; and a lower unit with a much greater potential. A small set of parameters has been identified which differentiate the typological units. These parameters allow a realistic estimation to be made of the ceramic properties of any clay layer sampled in the study area. It is anticipated that with minor field work and sampling, the typological column can also be used in adjacent areas.
\end{abstract}

Keywords Typological column - Mapping - Clays ·

Raw material $\cdot$ Classification $\cdot$ Ceramics

Résumé La cartographie des ressources en argiles dans les dépôts cénozoïques de la région de Tábua (centre du Portugal) a été réalisée, en même temps que la caractérisation chimique, minéralogique et technique de dix-sept

J. V. V. Lisboa ( $\square)$ · J. M. F. Carvalho · Á. Oliveira

Laboratório Nacional de Energia e Geologia (LNEG),

Estrada da Portela, Bairro do Zambujal-Alfragide,

Apartado 7586, 2720-866 Amadora, Portugal

e-mail: vitor.lisboa@lneg.pt

P. P. Cunha

Department of Earth Sciences, IMAR-Marine

and Environmental Research Centre,

University of Coimbra, Coimbra, Portugal échantillons d'argile. L'étude a été entreprise pour mettre en relation les unités lithostratigraphiques et la typologie des matières premières concernant l'industrie céramique. La séquence sédimentaire comprend deux unités présentant des caractéristiques différentes pour l'industrie céramique : une unité supérieure, avec des argiles qui présentent des contraintes techniques et une unité inférieure avec un potentiel beaucoup plus important. Un petit ensemble de paramètres a été identifié, permettant de différencier les unités typologiques. Ces paramètres permettent une estimation réaliste des propriétés de n'importe quelle couche d'argile de la région intéressant l'industrie céramique. On pense que des travaux limités de terrain et d'échantillonnage permettraient d'étendre ces conclusions à d'autres régions voisines.

Mots clés Colonne typologique - Cartographie - Argiles · Matières premières · Classification - Céramiques

\section{Introduction}

One of the main concerns of the ceramic industry is to obtain a permanent supply of raw material and maintain quality-controlled stocks in order to ensure the consistent quality of the final products. To meet these needs, besides mapping the locations of raw materials it is essential to know their mineral composition, textural properties and technological parameters.

Establishing a detailed lithological column helps the better identification of favourable layers. The typological column corresponds to a broader concept compared with the lithostratigraphical or lithological column, in that it goes beyond identifying the lithofacies and offers a first assessment of the suitability of the raw materials for use in 